\title{
The 1040th Anniversary Celebrations of Yuelu Academy
}

In 976 Zhu Dong 朱洞, prefect of Tanzhou, established the Yuelu Academy of Classical Learning 获麓書院. Thus did this school with a continuous history of over a thousand years get its start. In 1901 the academy was reorganized as the Hunan College of Higher Learning 湖南高等學堂, and after several changes, in 1926 it was renamed Hunan University 湖南大学. In the late 1970s and early 1980s the academy began restoring its traditional architecture and reviving its traditional curriculum and academic scholarship. Today Yuelu Academy is responsible for teaching and research in the fields of history and philosophy at Hunan University and has established a complete system for training professionals in these fields that includes undergraduate, master's, doctoral, and postdoctoral programs. In addition to programs appropriate for all different age groups, the academy also has specialized research groups with outstanding scholarly achievements and several research centers and platforms. It is truly a vibrant thousand-year-old seat of learning.

In 2016 the academy celebrated the 1040th anniversary of its founding by carrying out several programs connected with the academy's training professionals, conducting research, preserving culture, serving society, and transmitting culture. In particular, we carried out several activities celebrating scholarly culture, established two academic bases, organized seven scholarly conferences, held forty-four lectures, and organized such large-scale activities as a celebration of Chinese culture and a memorial ceremony for Confucius. Through these activities, we attracted people in the fields of academia, culture, and education from China and abroad to visit the academy and celebrate the flourishing of Chinese culture for over one thousand years.

On March 26, 2016, Hunan University established the Center for Organizing and Researching Rare Books 古籍整理研究所, and on June 5 it established the Center for Research on the Four Branches of Literature 中国 四库学研究中心, both under the direction of Professor Deng Hongbo 邓洪波. In the more than thirty years since the establishment in 1984 of the Cultural Research Institute 文化研究所 at Yuelu Academy, the academy has treated the organization and study of premodern literature as a central part of its research 
mission, and it has achieved a number of important results. These results have served as an excellent foundation for the establishment of these two centers.

This year also happens to be the thirtieth anniversary of the academy's revival of teaching and acceptance of its first class of history students. From April 15 to 17, 2016, we held a conference titled "The Academy's Education and Heritage" and carried out anniversary celebrations. Attending these activities were past and present faculty and staff, together with past and present students, a total of over three hundred people. The faculty and students fully discussed the academy's heritage and education, and the celebrations were plentiful and varied. Especially significant was our collecting oral history about the academy and our organization of materials about the history of the academy. In May 2016 the academy, together with the School of Confucianism 国学院 at Renmin University of China and the School of Chinese Classics 国学院 at Wuhan University, held a "National College Students Forum on Chinese Classics." In June the academy held an "Advanced Forum on the Study of the Four Branches of Literature" and, along with the Institute of Modern History of the Chinese Academy of Social Sciences, held a "Forum on the Culture of Decorum" and a "Conference Honoring the 100th Birthday of Mr. Shen Wenzhuo 沈文倬." Toward the end of October, it held the advanced forum "The Evolution and Transmission of the History of Confucianism." In November the academy, together with Center for the Study of Modern Chinese Thought of the Chinese Academy of Social Sciences, held the "Sixth International Conference on Modern Chinese Intellectual History." And in December it held the advanced forum "Letting Our Cultural Heritage Blend in with Contemporary Daily Life" and the twenty-sixth project conference on protecting major historical and cultural sites at the national level.

In recent years Yuelu Academy has gradually revived traditional temple rites, conducting both spring and autumn temple rites in 2016. In the spring we executed rites for the poet $\mathrm{Qu}$ Yuan 屈原 (ca.340-278 BCE) and Zhang Shi 張栻 (1133-1180), an early director of Yuelu Academy. The rites involved reciting poetry, singing songs, and cherishing the memory of these illustrious men. In the autumn we executed a rite for Confucius (ca.551-ca.479 BCE). In the temple to Confucius, we carried out in solemn fashion a traditional Zhou-period rite, performed ancient music, and read Confucian classics aloud.

Our most influential activity in 2016 was the Second Global Traditional Chinese Culture Awards Ceremony 第二届全球华人国学大典, held jointly by Yuelu Academy, Phoenix New Media 凤凰网, Phoenix Television 凤凰卫视, and Dunhe Foundation 敦和基金会, and lasting from May to October, a total of six months. The theme of the ceremony was "Paying respect to Chinese 
culture; becoming familiar with Chinese culture." Serving as general consultant for the ceremony was Xu Jialu 许嘉琒, a famous scholar and a vicechairman of the Standing Committee of the Ninth and Tenth National People's Congress. Offering technical support were the China Association for Yan Huang Culture 中华炎黄文化研究会, Society for the History of Chinese Philosophy 中国哲学史学会, China Association for Exegetical Research 中国 训诂学研究会, China Association for Qin and Han History 中国秦汉史研究会, China Society for Tang Literature 中国唐代文学学会, Chinese Confucian Academy 中华孔子学会, and China Confucius Foundation 中国孔子基金会. On May 17 the opening ceremony was held at the Beijing Palace Museum 北京 故宫博物院. And from October 27 to 29, there were six major events: two high-standard speaker discussions, two advanced forums on Chinese culture, a performance of Chinese music on Hexi Platform, and a Chinese-culture award ceremony. The academy thus made the Second Global Traditional Chinese Culture Ceremony the most successful possible. This happened because academic institutions, the media, and public welfare organizations joined together to make this event a veritable feast of Chinese culture that attracted a wide range of participants. After receiving over two hundred nominations from scholars worldwide and many Internet users, the Global Traditional Chinese Culture Ceremony, on the evening of October 29, announced its selections for thirty-seven awards for "accomplishments in the field of China studies," "the spread of China studies," and "life-time achievements in the field of China studies." The ceremony created a sensational reaction in scholarly circles, educational circles, and cultural circles. Owing to its fairness and authority, it has gradually become the world's most important celebration of Chinese culture, and it has greatly elevated the fame and reputation of Yuelu Academy.

Throughout the year, the academy held twenty-nine successful Minglun Tang Lectures. Invited lecturers included Xia Changpu 夏長樸 (Taiwan), Li Hongqi 李弘祺 (Taiwan), Li Xiaodong 李曉東 (Japan), Satō Masayuki 佐藤將 之 (Taiwan), Wu Genyou 吴根友, Zhang Xiping 张西平, Dong Ping 董平, Lou Jin 楼劲, and Gu Hongyi 顾宏义. We also celebrated the 200th Minglun Tang Lecture. Moreover, the academy held fifteen Yuelu Academy Lectures. Invited to lecture were Luo Jintang 羅錦堂 (United States), Xia Changpu, Zhang Qizhi 张岂之, Sun Ji 孙机, and the brothers Tang Yiming 唐翼明 and Tang Haoming 唐浩明. Phoenix Net webcast these lectures over the Internet. A total of 5,000 people attended these lectures, and on line there were a total of 3 million views.

In addition, in the area of construction, the Yuelu Academy Classroom and History Exhibition Hall reopened. The major structures on which construction has been completed are the Hexi Platform, head gate, main gate, 
gate no. 2, and lecture hall, which were renovated for the first time in thirty years in connection with the 2016 anniversary celebrations.

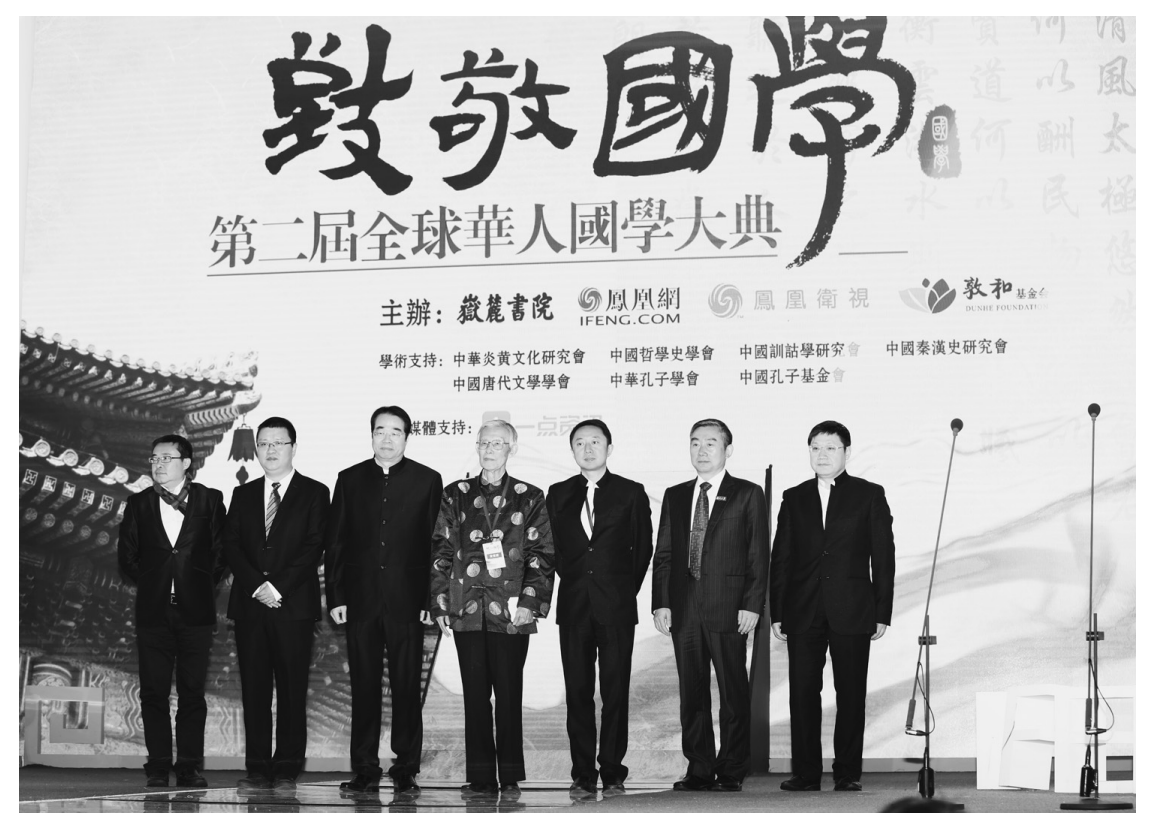

Ceremony in memory of Confucius (2015)

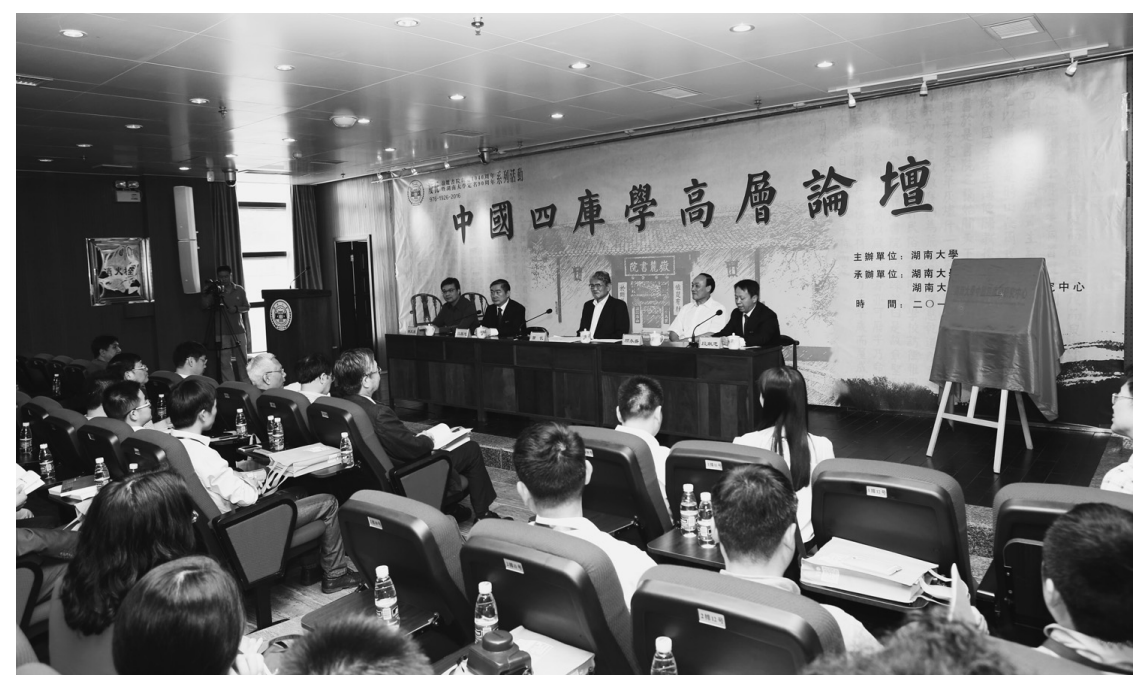

Conference on the Study of Siku Quanshu (June 5, 2016)

(Complete Library in Four Branches of Literature) 


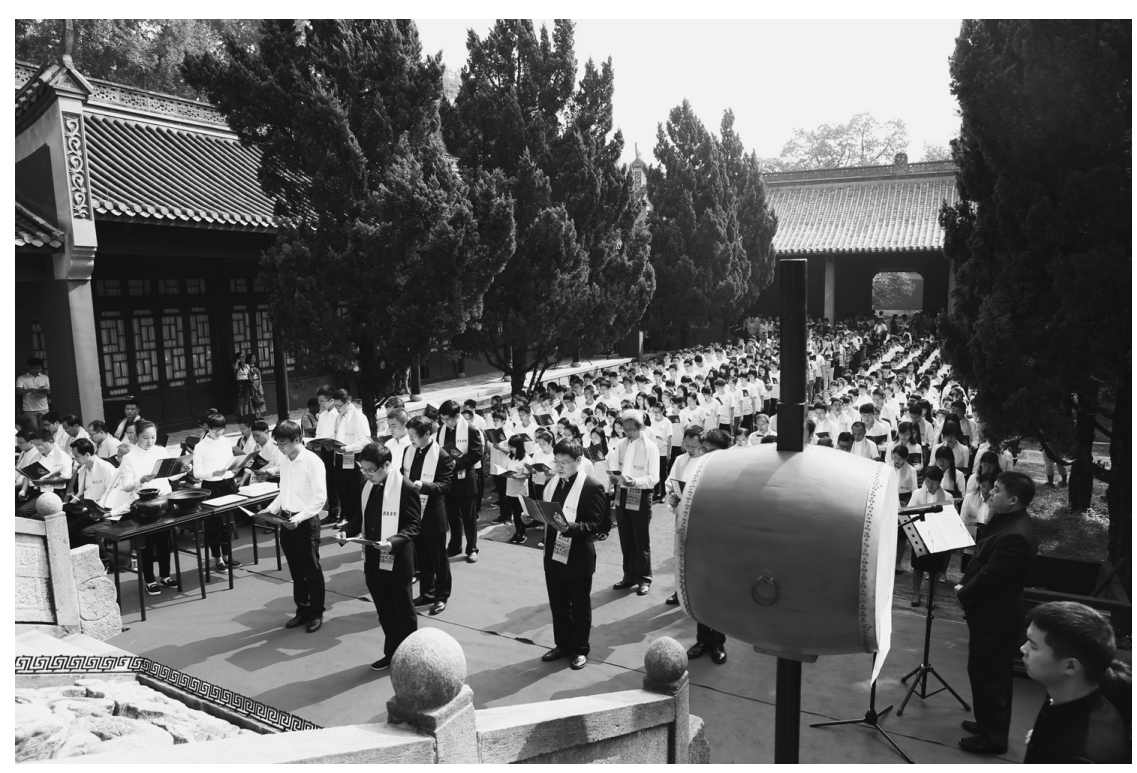

Ceremony for Study of Ancient Chinese Civilization by Chinese People around the World (October 29, 2016) 